\title{
Comparison of Parallel Dowel-Bearing Strength of Mengkulang, Kempas and Pine Glulam between ASTM D 5764-97a and BS EN 383: 2007
}

\author{
Nor Jihan A. Malek ${ }^{1 *}$, Rohana Hassan², Azmi Ibrahim ${ }^{3}$, Hussein M. H. Almanea ${ }^{1}$, Tee H. Hean ${ }^{1}$ \\ ${ }^{I}$ Faculty of Engineering and Built Environment, SEGi University, 47810 Petaling Jaya, Selangor, Malaysia \\ ${ }^{2}$ Engineered Wood Product Research Group (EWPro), Universiti Teknologi MARA, 40450 Shah Alam, Selangor, Malaysia \\ ${ }^{3}$ Faculty of Civil Engineering, Universiti Teknologi MARA, 40450 Shah Alam, Selangor, Malaysia \\ *Corresponding author E-mail: norjihan.abdmalek@gmail.com
}

\begin{abstract}
Dowel-bearing strength is a significant parameter for designing wood connection. The strength of timber connection can be influenced by the bolt diameter, wood grain direction either parallel or perpendicular, thickness of wood, moisture content and other parameters. The dowel-bearing strength test was conducted with a $12 \mathrm{~mm}$ bolt diameter dowel, for three different types of timber species, which were mengkulang (Heritiera sp.), kempas (Koompassia malaccensis) and pine (Pinus sp.) glulam. The dowel was placed parallel to the timber grain direction with a glue line at the center of the half-hole test. The 5\% diameter offset load $\left(\mathrm{F}_{5 \%}\right)$ for dowel-bearing strength $\left(\mathrm{F}_{\mathrm{y}}\right)$ was determined by using the ASTM D 5764-97a whereas the dowel-bearing strength $\left(\mathrm{F}_{\mathrm{h}}\right)$ was determined based on BS EN 383: 2007. The results of the three different types of wood showed that the Malaysian timber kempas and mengkulang were $51.740 \%$ and $32.966 \%$, respectively, which were higher than the European timber pine. The results of the dowel-bearing strengths $\left(\mathrm{F}_{\mathrm{h}}\right)$, which were based on the BS EN 383: 2007 gave higher values compared to ASTM D 5764-97a.
\end{abstract}

Keywords: Dowel-bearing strength; half-hole test; parallel to grain; mengkulang; kempas; pine.

\section{Introduction}

Based on Qiu et.al, [1], the functions of glulam include increasing strength and versatility of wood. Glulam has many applications including as a straight horizontal beams or vertical columns as well as arched and curved shapes. Dowel-bearing strength is an important parameter that needs to be determined for a safe connection design. Therefore, dowel bearing capacity requires the understanding of the influences of specific gravity, dowel diameter and loading direction [2]. The European Yield Model (EYM) is the basic criteria for designing dowel-type connection 'laterally loaded'. This approach considers geometry, yield stress, and bearing strength to approximate the yield load for connection. Dowelbearing strength is the resistance of the embedded portion of the dowel. Whale and Smith, [3] associated the bearing strength to two parameters, which are density of wood and dowel diameter for bolts and nails.

Wilkinson [4] carried out an investigation for different sample species, sizes and loading to examine the dowel type influence on wood. Rammer [5] reported the diameter of the bolt, which affected the bolt-bearing stiffness. Rammer and Winistorfer [6] claimed that moisture content affected the dowel-bearing strength. Hassan [7] highlighted that there are some important parameters required to determine the load carrying capacity of joints for designing purposes such as dowel diameter, density, specific gravity, bearing strength and load direction. Seri et al. [8] mentioned that the dowel-bearing strength reduced inversely proportional with dowel diameter.
In addition, the dowels were embedded on the sample in the half holes, and were uniformly loaded on the longitudinal axis of the dowels, at a constant rate of $1 \mathrm{~mm} / \mathrm{min}$. In the experiments three types of loads were of interest, which were the proportional limit load, yield load, maximum load and 5\% off-set load. The 5\% off set load was used to determine the bearing strength and yield load of connections. Thus, this study was conducted to determine the dowel-bearing strength parallel to grain for mengkulang, kempas and pine glulam with a $12 \mathrm{~mm}$ bolt diameter dowel and to compare the dowel-bearing strength value between mengkulang versus pine, and kempas versus pine by using ASTM D5764-97a [9] and BS EN 383: 2007 [10] standards.

\section{Methodology}

The dowel-bearing strength tests for mengkulang, kempas and pine glulam with glue line were tested using a universal testing machine. The experiment was carried out in accordance to the procedures as stipulated in BS EN 383: 2007 [10]. Based on ASTM D5764-97a [9], the experiment for dowel-bearing adopted the half-hole diameter test. With reference to ASTM D5764-97a [9] and BS EN 383: 2007 [10], the main difference between these two equations is on the value of the force, $\mathrm{F}$, which was taken during the experiment. The ASTM D5764-97a [9] uses the 5\% diameter offset load to obtain the dowel-bearing strength $\left(\mathrm{F}_{\mathrm{y}}\right)$ while BS EN 383: 2007 [10] uses the value of maximum load, $\mathrm{F}_{\max }$ to obtain the dowel-bearing strength $\left(\mathrm{F}_{\mathrm{h}}\right)$. In total, 27 samples, 
having dimension of $50 \times 50 \times 50 \mathrm{~mm}$ were tested using the dowel-bearing strength test with the half-hole method. Fig. 1(a) shows a band saw machine, which was used to cut all the samples while a drilling machine (Fig. 1(b)) was used to drill into the wood. Then, a hole drill (Fig. 1(c)) was used for bolt assembly, and Fig. 1(d) shows the sample for parallel to grain test. Fig. 2 shows the halfhole test setup where the dowel had been pressed onto the block samples with a constant loading rate of $0.04 \mathrm{in} / \mathrm{min}(1 \mathrm{~mm} / \mathrm{min})$. According to ASTM D 5764-97a [9], Equation (1) below was used to compute the dowel-bearing strength from the experiment using the $5 \%$ offset load method:

$\mathrm{F}_{\mathrm{y}}=\mathrm{F}_{5 \%} / \mathrm{dt}$

where:

$\mathrm{F}_{\mathrm{y}}=$ dowel-bearing strength

$\mathrm{F}_{5 \%}=5 \%$ offset load

$\mathrm{d}=$ diameter of the bolt

$\mathrm{t}=$ thickness of the sample

Based on BS EN 383: 2007 [10], Equation (2) below was used to calculate the dowel-bearing strength for each sample.

$\mathrm{F}_{\mathrm{h}}=\mathrm{F}_{\max } / \mathrm{dt}$

where:

$\mathrm{F}_{\mathrm{h}}=$ dowel-bearing strength

$\mathrm{F}_{\max }=$ maximum load

$\mathrm{d}=$ diameter of the bolt

$\mathrm{t}=$ thickness of the sample

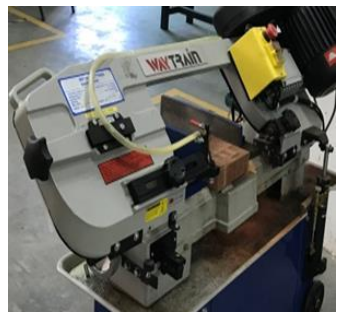

(a) Bandsaw machine

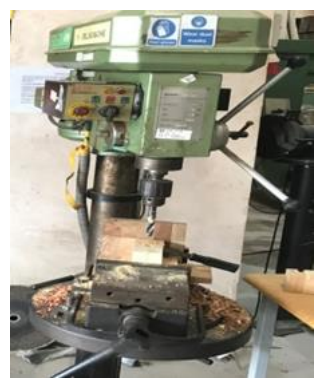

(b) Drilling machine

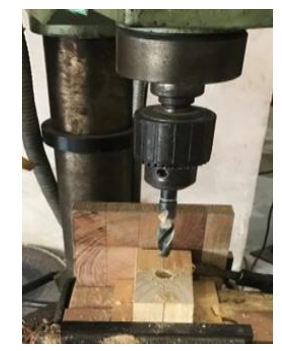

c) Hole drill

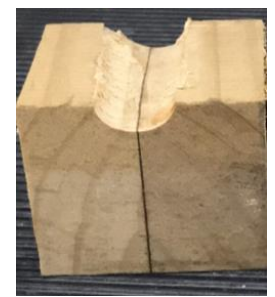

d) Sample for parallel to grain test

Fig. 1: Preparation of half-hole sample for bearing test

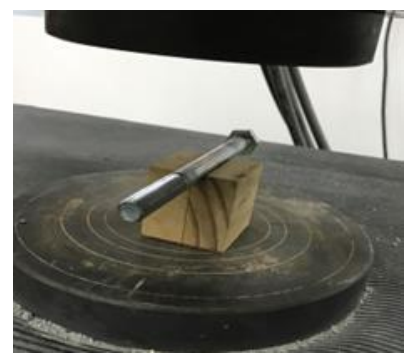

Fig. 2: Half-hole test

\section{Results and Discussion}

Table 1 shows the average values of dowel-bearing test of glulam manufactured from mengkulang, kempas and pine species that were calculated based on ASTM D5764-97a [9] for $F_{y}$ and BS EN 383: 2007 [10] for $F_{h}$. There was a total of nine samples for each timber species. Kempas had the highest values of dowel-bearing strength for both standards while pine obtained the lowest.

Table 1: Average values of dowel-bearing strength between ASTM D 5764-97a and BS EN 383: 2007

\begin{tabular}{|c|c|c|}
\hline $\begin{array}{c}\text { Type } \\
\text { of timber }\end{array}$ & $\begin{array}{c}\text { ASTM D 5764-97a } \\
\text { Dowel-bearing strength, } \\
\mathbf{F}_{\mathbf{y}} \mathbf{~ N / m m}\end{array}$ & $\begin{array}{c}\text { BS EN 383: 2007 } \\
\text { Dowel-bearing strength, } \\
\mathbf{2}\end{array}$ \\
\hline Mengkulang & 17.788 & 22.645 \\
\hline Kempas & 24.708 & 26.771 \\
\hline Pine & 11.924 & 16.769 \\
\hline
\end{tabular}

Fig. 3 shows the results of dowel-bearing strength and species based on ASTM D 5764-97a [9]. The comparison of dowelbearing strength between mengkulang and pine was $32.97 \%$. It shows that both sample failed in bearing; however, pine failed abruptly under the fastener during loading. The relationship between moisture content (MC) and dowel-bearing strength has affected the failure, but it is not dependent on species and fastener type as proved by Rammer and Winistorfer [5]. Fig. 4 shows the results of dowel-bearing strength for different wood species based on BS EN 383: 2007 [10]. The comparison of dowel-bearing strength between kempas and pine was $51.74 \%$ and the kempas sample failed under bearing compression. The standard error bars between mengkulang and kempas versus pine mean values are not overlapping; hence, the mean was statically significant.

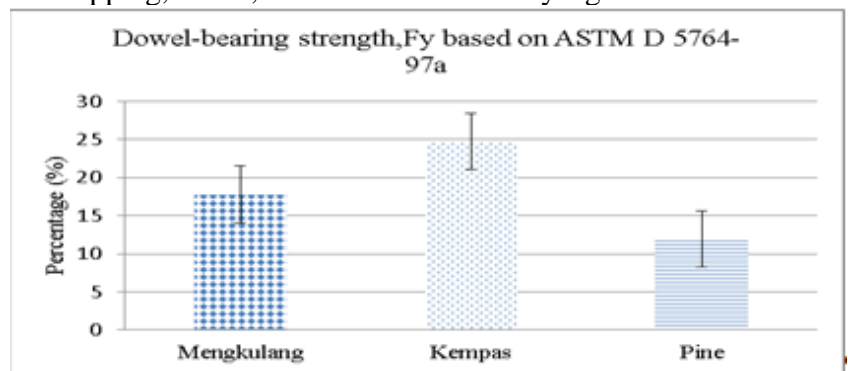

Fig. 3: Dowel-bearing strength of different wood species based on ASTM D 5764-97a 
Dowel-bearing strength,Fh based on BS EN 383:2007

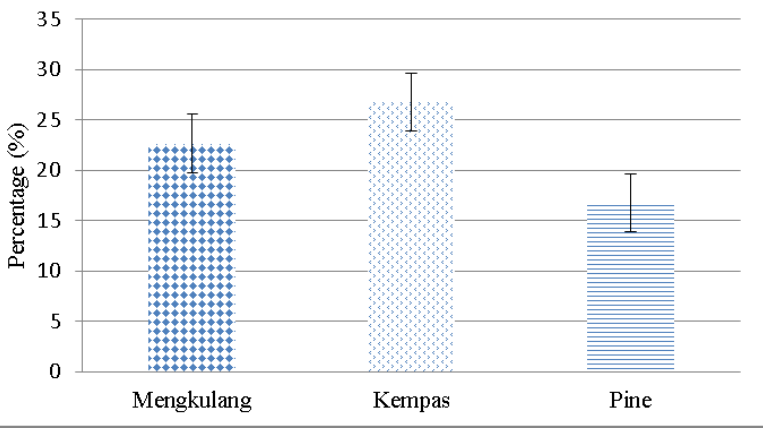

Fig. 4: Dowel-bearing strength of different wood species based on BS EN 383: 2007

Fig. 5 shows a typical failure of the sample after test for parallel to the grain with glueline of mengkulang, kempas and pine glulam samples. The samples were found partially cracked about $20 \%$ along the glueline and $80 \%$ along the wood grain.

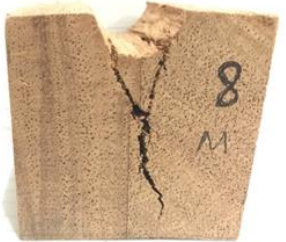

Fig. 5: Typical failure of the sample

Fig. 6 shows mengkulang versus pine species, when subjected to dowel-bearing load parallel to the grain, the differences between dowel-bearing strength was $32.966 \%$. It showed that mengkulang has higher value of dowel-bearing strength which has failed in bearing and there was a sound of crack when it reached the maximum load. It shows that the standard error bars between mengkulang and Pine mean value is overlapping, so the mean is not statically significant $(\mathrm{P}>0.05)$. Fig. 7 shows that kempas species when subjected to dowel-bearing load parallel to the grain, and the percentage different in the dowel-bearing strength value determined was $51.740 \%$ compared to pine. It showed that Kempas had a higher dowel-bearing strength during loading and the sample was failed abruptly while it was approaching the maximum load while pine was in a dry condition that caused the value of the dowelbearing strength lower than kempas. The standard error bar between kempas and pine mean value was overlapping, which indicated that they were not statically significant $(\mathrm{P}>0.05)$.

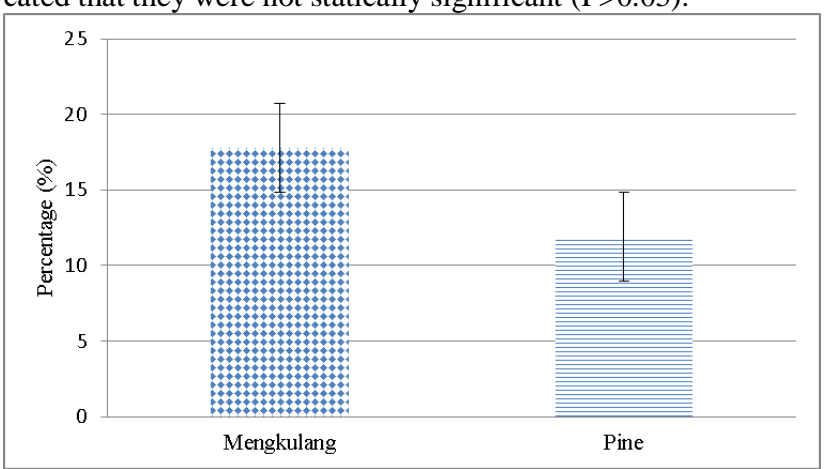

Fig. 6: Percentage difference of dowel-bearing strength for mengkulang and pine

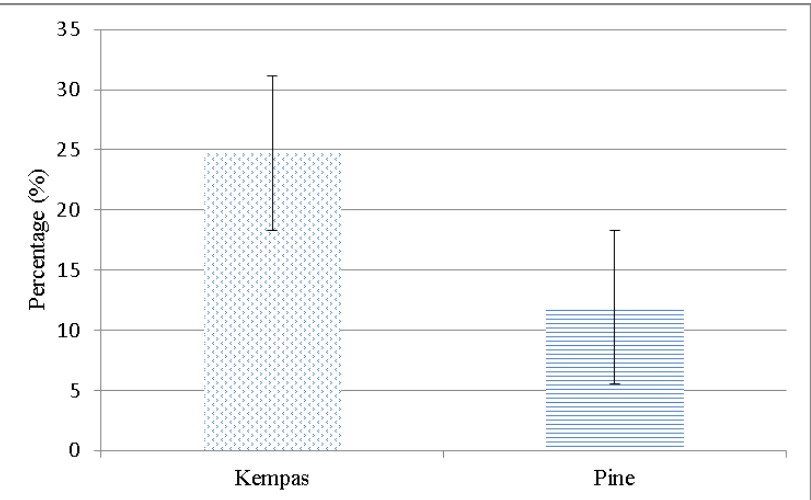

Fig. 7: Percentage difference of dowel-bearing strength for kempas and pine

\section{Conclusion}

In conclusion, the dowel-bearing strength values based on BS EN 383: 2007 were higher than ASTM D5764-97a. For mengkulang species, a difference of $21.45 \%$ was observed with the use of BS EN 383: 2007 standard as compared to the ASTM D5764-97a. While for kempas, BS EN 383: 2007 produced a higher percentage value of $7.71 \%$ as compared to ASTM D5764-97a. For pine species, BS EN 383: 2007 showed a higher percentage value of $28.89 \%$ as compared to ASTM D5764-97a. The percentage differences reported in this study were based on two different fundamental theories as proposed by ASTM D5764-97a and BS EN 383: 2007 , respectively.

\section{Acknowledgement}

The authors would like to acknowledge SEGi University, Kota Damansara for the support on this research and Universiti Teknologi MARA (UiTM) Shah Alam for the assistance in the laboratory work.

\section{References}

[1] Qiu, J., Tong J., \& Chen L. (2013) Comparison of Various Glulam in Physical Properties and Flexural Behaviors. Applied Mechanics and Materials, 368-370 (Aug 2013), 880-883.

[2] NFPA 1986. National design specification for wood construction. National Forest Products Association, 1250 Connecticut Avenue, NW., Washington, DC.

[3] Whale, L.R.J., Smith I (1986) Mechanical Joints in Structural Timberwork - Information for Probabilistic Design. Timber Research and Development Association, Buckinghamshire, England.

[4] Wilkinson, T.L., (1991) Dowel bearing strength. USDA Res Paper FPL-RP-505, For Prod Lab, Madison, WI

[5] Rammer, D.R., (1999) Parallel-to-grain Dowel-bearing Strength of Two Guatemalan Hardwoods. FOREST PRODUCT JOURNAL, JUNE 1999, V. 49(6) pp. 77-87.

[6] Rammer, D.R., Winistorfer, S.G., (2001) Effect of moisture content on dowel-bearing strength. WOOD AND FIBER SCIENCE, JAN UARY 2001, V. 33(1) pp. 126-139.

[7] Hassan, R., Hamid, S., Amini, N.A.M., Hussin, T.A.R. (2014) Evaluation of Dowel-Bearing Strength for Wood Dowel Using 'Spring Theory'. Proceedings of the International Civil and Infrastructure Engineering Conference 2014. InCIEC 2013. Springer, Singapore, ISBN 978-981-287-290-6 (pp.75).

[8] Kim HS \& Jeong HS (2007), A nurse short message service by cellular phone in type-2 diabetic patients for six months. Journal of Clinical Nursing 16, 1082-1087.

[9] Seri N.A.B., Nurddin M.F.B., Hassan R.B. (2016) Dowel-Bearing Strength Properties of Glulam With and Without Glue Line Made of Mengkulang Species. Proceedings of the International Civil and Infrastructure Engineering Conference 2016. InCIEC 2015. Springer, Singapore, ISBN 978-981-10-0155-0 (pp. 725-734).

[10] American Society for Testing and Materials (2007). Standard Test Method for Evaluating Dowel-Bearing Strength of Wood and 
Wood-Based Products. American Society of Testing and Materials Designation D 5764-97a.

[11] BS EN 383: 2007, 'Timber Structures, Test MethodsDetermination- of Embedment Strength and Foundation Values for Dowel Type Fasteners'. 